\title{
Hepatitis $C$ virus infection status and associated factors among a multi-site sample of people who used illicit drugs in the Amazon region
}

\author{
Aldemir B. Oliveira-Filho ${ }^{1 *}$ (D, Francisco Junior A. Santos ${ }^{1}$, Fabricio Quaresma Silva ${ }^{1}$, Nairis Costa Raiol ${ }^{1}$, \\ Camila Carla S. Costa ${ }^{1,2}$, Juliana Nadia F. Piauiense ${ }^{1,2}$, Luisa Caricio Martins ${ }^{2}$, Yasmin Maria N. Cardoso ${ }^{3}$, \\ Jeruza Ferraz F. Di Miceli ${ }^{3}$, Rafael Lima Resque ${ }^{3}$, Gláucia C. Silva-Oliveira' ${ }^{1}$, Luiz Marcelo L. Pinheiro ${ }^{4}$, \\ Luiz Fernando A. Machado ${ }^{5}$, João Renato R. Pinho ${ }^{6}$, José Alexandre R. Lemos ${ }^{7}$, Emil Kupek ${ }^{8}$ and \\ Benedikt Fischer ${ }^{9,10,11}$
}

\begin{abstract}
Background: Elevated rates of Hepatitis C Virus (HCV) infection have been reported in epidemiological studies with people who used illicit drugs (PWUIDs) in different Brazilian regions. In Brazil's Amazon region, studies have already identified the common use of illicit drugs among adolescents and the high prevalence of HCV infections among PWUIDs. However, all studies done with PWUIDs were conducted with small samples and within limited geographic coverage. This study determined the prevalence and risk factors for HCV infection in PWUIDs in the Amazon region, northern Brazil, as well as estimating the prevalence and factors associated with the HCV spontaneous clearance (HSC).

Methods: This cross-sectional study accessed 1666 PWUIDs from multiple municipalities of the Amazon region. Sociodemographic, economic, drug use and health-related information were collected through interviews. Blood samples collected were tested for the presence of anti-HCV antibodies and RNA-HCV. HCV genotypes were identified by realtime polymerase chain reaction (PCR). Logistic regressions were run to identify factors independently associated with HCV infection status and HSC.

Results: In total, 577 (34.6\%) featured HCV antibodies, of which 384 (23.1\%) had active HCV infection and 193 (11.6\%) indicated HSC. Genotypes 1 (80.2\%) and 3 (18.8\%) were detected. HCV infection status was associated with the length of illicit drug use history, factors related to parenteral and sexual transmission, and factors of socio-economic marginalization leading to potential risk activities for HCV. HSC was associated with the ethnic (including indigenous) background of participants.

Conclusions: High levels of HCV infection were detected in PWUIDs. Genotype 1 was predominant. Intense use of illicit drugs, unprotected sexual intercourse, high number of sexual partners and social marginalization were associated with all HCV infection. HSC was associated with origin (Amazonian-born) and non-white (e.g., Black or Indigenous) of PWUIDs. These findings emphasize the need for improve HCV prevention and control services and care for PWUIDs in the Brazilian Amazon region.
\end{abstract}

Keywords: HCV, Epidemiology, Spontaneous clearance, People who used illicit drugs, Brazil, Amazon

\footnotetext{
* Correspondence: olivfilho@ufpa.br

'Laboratório de Células e Patógenos, Grupo de Estudo e Pesquisa em

Populações Vulneráveis (GEPPOV), Instituto de Estudos Costeiros, Campus de

Bragança, Universidade Federal do Pará, Alameda Leandro Ribeiro, s/n.

Aldeia, Bragança, PA, Brazil

Full list of author information is available at the end of the article
}

(c) The Author(s). 2019 Open Access This article is distributed under the terms of the Creative Commons Attribution 4.0 International License (http://creativecommons.org/licenses/by/4.0/), which permits unrestricted use, distribution, and reproduction in any medium, provided you give appropriate credit to the original author(s) and the source, provide a link to the Creative Commons license, and indicate if changes were made. The Creative Commons Public Domain Dedication waiver (http://creativecommons.org/publicdomain/zero/1.0/) applies to the data made available in this article, unless otherwise stated. 


\section{Background}

The hepatitis $\mathrm{C}$ virus (HCV) infection causes acute and chronic liver disease and may lead to cirrhosis, liver failure or hepatocellular carcinoma [1]. Globally, it is estimated that there are approximately 100 million persons with serological evidence of active or non-active $\mathrm{HCV}$ infection, and that $\mathrm{HCV}$ causes about 700,000 deaths each year [2]. Most cases of acute infection are asymptomatic and remain undiagnosed [3]. Currently highly effective pharmacotherapeutic (direct-acting antiviral) treatment options for HCV are now available [4]. Spontaneous clearance of $\mathrm{HCV}$ can occur within 12 months of infection in $15-45 \%$ of infected individuals, in the absence of treatment [5]. HCV infection does not result in long-term immunity and reinfection after effective treatment or clearance has been reported [6]. In epidemiological scenarios with high prevalence of $\mathrm{HCV}$, multiple exposures may result in infections with $\mathrm{HCV}$ of more than one distinct genotype in the same person [7].

Illicit drug use - especially by injection and sharing non-sterile or shared injection equipment - is a main risk factor for transmission of $\mathrm{HCV}$ [8]. Many people who used illicit drugs (PWUIDs) infected with HCV are asymptomatic and/or unaware of their infection, and the continuation of risk activities that contribute to further transmission and an increase in the incidence of $\mathrm{HCV}$ [9]. Estimates indicate that there are about 16 million individuals who inject drugs worldwide, and unsafe use or sharing of drug paraphernalia (mainly syringes/needles used for drug injecting) is the main agent of virus transmission among users [10, 11]. As many as 10 million people who inject drugs may be HCV-infected worldwide, reflecting the strong association of these risk activities with the easy spread of the virus $[10,12]$.

Brazil is one of the emerging economies where the use of mostly stimulant drugs, such as cocaine - used intranasally (powder) or smoked (crack-cocaine and its related forms - merla or oxi) - has increased significantly in the last two decades [13-15]. Although uncommon, the use of injectable cocaine has been documented also $[13,16,17]$. There are several reasons for the high rate of cocaine-products used in Brazil: geographic proximity and un-secured borders with the world's largest cocaine producers (Peru, Colombia and Bolivia), a young population combined with increases in wealth in the last decade, and the extensive availability combined with the cheap price of cocaine in Brazil (one crack 'stone' selling for three Reais, equivalent to US\$ 1) $[15,18]$.

Elevated rates of $\mathrm{HCV}$ infection have been reported in epidemiological studies with PWUIDs in different Brazilian regions (2 to 29\%) [19-23]. In the Amazon region (Northern Brazil), studies with PWUIDs have indicated a higher prevalence of $\mathrm{HCV}$ infection (28 to 37\%), highlighting the elevated potential for the acquisition and transmission of $\mathrm{HCV}$ in this risk population [16, 17, $24,25]$. HCV genotype 1 is predominant among HCVinfected PWUIDs. Several risk factors for $\mathrm{HCV}$ infections have been reported: age ( $\geq 35$ years), tattoos, domestic re-use of needles or syringes for medical procedures, injecting drug use, sharing of drug paraphernalia, daily and lengthy drug use histories ( $>3$ years). However, all studies done with PWUIDs were conducted with small samples and with limited geographic coverage $[16,17,24,25]$.

The vast Amazon region in Northern Brazil is a relatively isolated and socio-ecologically diverse environment, with only limited infrastructure and public services. In the Amazon region, studies have already identified the high use of illicit drugs among adolescents and the high prevalence of $\mathrm{HBV}$ and $\mathrm{HCV}$ infections among PWUIDs $[17,26,27]$. In this context, this study assessed a sample of 1666 PWUIDs in the Amazon region (Northern Brazil), collecting relevant epidemiological information on HCV infection and related risk factors and outcomes towards improved understanding of HCV transmission pathways and intervention needs in this particular risk population and socio-geographic context.

\section{Methods}

\section{Study sample and setting}

This cross-sectional study relied on biological and selfreported socio-behavioral data from a convenience sample of PWUIDs from the municipalities of the state of Amapá and Pará, in the Amazon region (Northern Brazil) (Fig. 1). Sample recruitment occurred by way of snowball technique $^{16}$. In neighborhoods of the study sites known to be areas of intensive drug consumption, community leaders and other potential recruitment facilitators were identified and invited to assist with participant recruitment for the study. These study facilitators disseminated general information about the study and its objectives in their respective communities, and identified and invited PWUIDs and their relatives and friends as potential study participants. Study eligibility criteria were: (1) use of illicit drugs in the last three months; (2) 18 years of age or older, (3) not under the effect of psychotropic drugs during the meeting with some members of the study team, (4) did not present a risk of death to researchers in the municipality, and (5) willingness to comply with the study protocol, i.e. to provide a biological sample, to complete the epidemiological assessment, and to provide informed consent for study participation.

In each municipality, meetings between researchers and facilitators were held in order to establish the approximate number of PWUIDs to be recruited in each neighborhood, and the local recruitment and assessment procedures to perform the data collection. Potential study candidates were screened for study eligibility 




Fig. 1 Geographical location of municipalities in the Amazon region that people who used illicit drugs (PWUIDs) were accessed. The Brazilian states of Amapá and Pará are represented by the abbreviations AP and PA, respectively. The numbers from 1 to 38 indicate the municipalities where blood samples were collected and information was provided by the PWUIDs (more details on Additional file 1: Figure S1)

(based on the study's inclusion criteria) during specific field research times in each of the research settings; this procedure was repeated on several occasions. If eligible and consented for the study, participants underwent the study assessment procedures in a private, confidential setting. Several spaces were used to hold meetings with PWUIDs, such as: private rooms in commercial establishments, rooms part of the Universidade Federal do Pará (UFPA) and Universidade Federal do Amapá (UNIFAP), public health facilities, private rooms within schools, churches, and community centers. Members of the research team conducted the interview-based assessments and blood collection of the PWUIDs. All sample and data collections, as well as the formal consents for study participation, were provided on the specific day for each neighborhood of the different municipalities. No PWUIDs received financial incentive to participate in this study. All samples and data were collected between March 2013 and January 2018.

\section{Data collection}

All study participants completed an intervieweradministered questionnaire consisting of question items on socio-demographic, drug use and select clinical/ health and behavior outcome variables used in previous studies with similar target populations. The questionnaire contained question items in regards to the following variables: sex, age, colour/race, ethnic origin, marital status, education, amounts and sources of income (last 12 months), blood transfusion and surgical history, tattoos, history and frequency of illicit and other drug use (last 12 months), injection drug use (last 24 months), sharing of drug use equipment (last 12 months), presence of oral or nasal mucosal sores (last 12 months), sexual risk practices (last 12 months), presence of genital ulcers (last 12 months), police arrest/detention (last 12 months), involvement in illicit drug trafficking (last 12 months), and sex work involvement (last 12 months) $[16,24]$. In this study, unprotected sexual intercourse and multiple sexual partners were considered sexual risk practices.

\section{Laboratory tests}

Venous blood samples were taken from participants and tested for HCV infection. Specifically, a small blood sample $(5 \mathrm{ml})$ was collected in sterile tubes, allowed to 
clot, and centrifuged at room temperature. The resulting plasma samples were stored at a temperature below $-10^{\circ} \mathrm{C}$. At the end of the collection period at each study site, the samples were transported to UFPA and UNIFAP virological testing laboratories located in Belém, Bragança, Breves and Macapá for laboratory testing. The samples collected were tested for the presence of anti$\mathrm{HCV}$ antibodies and ribonucleic Acid - HCV (HCVRNA). Anti-HCV antibody was detected using enzyme immunoassay (EIA - Murex anti-HCV 4.0, DiaSorin). The samples were also submitted for the isolation of RNA (QIAmp Viral RNA Mini extraction kit, Qiagen) and transcription of RNA to complementary DNA (cDNA) (High-Capacity cDNA Reverse Transcription kit, Applied Biosystems). These two experiments were performed employing commercial kits according to the manufacturers' instructions. The $5^{\prime}$ untranslated region (UTR) fragment of HCV was detected by real-time polymerase chain reaction (PCR) [17]. When samples were found to be reactive for anti-HCV but negative for HCV-RNA, further confirmation was done using Immuno Blot Assay (RIBA, Chiron). PWUIDs were categorized as actively infected with $\mathrm{HCV}$ if they had a positive HCV-RNA and a positive antibody-HCV test. PWUIDs with non-active (past) HCV infection - or spontaneous clearance - were identified when they had a positive antibody-HCV test and a negative HCV-RNA test. The samples presenting HCV-RNA had their genotypes identified by real-time PCR [17].

\section{Data processing and statistical analysis}

All study data collected - including epidemiological indicator data from the participants' questionnaires - were entered into an Excel database and converted to SPSS. The proportion of participants who had active $\mathrm{HCV}$ and non-active (past) $\mathrm{HCV}$ infection was assessed. Confidence intervals were computed to estimate the prevalence of $\mathrm{HCV}$ infection rates. A descriptive analysis was conducted to investigate the bivariate relationships between $\mathrm{HCV}$ status and epidemiological (i.e., socio-demographic, drug use and other health-related) covariates drawn from the epidemiological questionnaire data. All the potential factors with probabilities of $p \leq 0.2$ were examined and included in the final models of $\mathrm{HCV}$ infection (i.e. active + non-active infections) and HCV spontaneous clearance (HSC) status, using backward stepwise multiple logistic regression. Multiple logistic regressions were then run to determine the association of each factor with HCV infection and HSC status. Various possible types of interactions were evaluated in order to determine how they might improve the final models [28]. The fit of the final model was assessed using the HosmerLemeshow goodness-of-fit test. All statistical analyses were performed using SPSS 20.0 for Windows, with a level of significance of 0.05 .

\section{Results}

\section{Characteristics of PWUIDs}

Of the total sample of 1666 participants recruited into the study, 539 PWUIDs were from nine municipalities of the state of Amapá (32.4\%) and 1127 PWUIDs were from twenty-nine municipalities of the state of Pará (67.6\%) (Fig. 1). The number of PWUIDs accessed in each municipality is available in the supporting information (Additional file 1: Figure S1). Respective majorities of the PWUIDs sample were male, aged between 18 to 29 years, heterosexual, single, Brazilian and born in the Amazon region, non-white and with a low/limited level of education. Most participants reported their initial onset of illicit drug use during adolescence, i.e. below the age of 18 years $(64.9 \%)$. The average monthly income of PWUIDs was around the Brazilian minimum wage standard (approximately 210 US dollars/month), derived from formal or informal employment sources (Table 1).

All PWUIDs reported frequent use of non-injected drugs in the last 12 months. A sub-group of PWUIDs reported injecting drug use (cocaine) at least once (last 24 months) (14.9\%). Most PWUIDs had used illicit drugs for a period of between 5 to 15 years $(60.3 \%)$, with an average period of 7.5 years. Crack-cocaine or related products (oxi) was the main drug used by most participants (50.2\%) (Table 2). Most PWUIDs reported using more than one illicit drug during their lifetime (92.2\%), commonly involving marijuana as the initial illicit drug used. The sharing of drug use equipment was common among PWUIDs $(n=988,59.3 \%)$ (Table 2$)$, specifically inhalation-pipe sharing was reported by many users of non-injecting drugs $(n=795,47.7 \%)$, and syringe and needle sharing among injecting drug users $(n=193$, 11.6\%). Some crack-cocaine users reported sores in their oral or nasal mucosa (34.5\%). Participation in the distribution or sale of illicit drugs (17.0\%) and a history of police or in prison detention (23.4\%) was reported by some PWUIDs (Table 2). Many users reported risky sexual practice or compromised sexual health, including multiple sexual partners and sex work involvement (34.8\%), and genital ulcers (46.9\%).

\section{HCV infection status and distribution of genotypes}

In total, 577 PWUIDs (36.6\%) had anti-HCV antibodies by EIA. Among these, 384 PWUIDs also featured HCVcDNA (23.0\%), indicating active HCV infection. Conversely, 193 PWUIDs had anti-HCV antibodies by EIA and immune-blot, with absence of HCV-cDNA by realtime PCR (11.6\%), indicating non-active HCV infection, and presented with presumed spontaneous clearance of HCV (Tables 1, 2 and 3). In PWUIDs with HCV-cDNA, genotypes $1(80.2 \%)$ and $3(18.8 \%)$ were identified, including four co-infections with these $\mathrm{HCV}$ genotypes (1.0\%) (Table 3). 
Table 1 Socio-demographic and economic characteristics of the sample of people who used illicit drugs related to the status of HCV infection

\begin{tabular}{|c|c|c|c|c|}
\hline \multirow[t]{2}{*}{ Characteristics } & \multirow[t]{2}{*}{$\mathrm{N}$} & \multicolumn{3}{|c|}{ HCV infection } \\
\hline & & Active \% (n) & Non-active \% (n) & Total \% (n) \\
\hline Total sample & 1666 & $23.0(384)$ & $11.6(193)$ & $34.6(577)$ \\
\hline \multicolumn{5}{|l|}{ Sex } \\
\hline Male & 1053 & $23.8(251)$ & $10.5(111)$ & $34.3(362)$ \\
\hline Female & 600 & $22.0(132)$ & $13.7(82)$ & $35.7(214)$ \\
\hline Transgendered & 13 & $7.7(1)$ & $0.0(0)$ & $7.7(1)$ \\
\hline \multicolumn{5}{|l|}{ Age } \\
\hline 18-29 years & 893 & $21.1(188)$ & $13.1(117)$ & $34.2(305)$ \\
\hline 30-39 years & 575 & $21.0(121)$ & $8.9(51)$ & $29.9(172)$ \\
\hline $40+$ years & 198 & $37.9(75)$ & $12.6(25)$ & $50.5(100)$ \\
\hline \multicolumn{5}{|l|}{ Origin } \\
\hline Brazilian - Born in the Amazon region & 1426 & $21.0(299)$ & $13.1(187)$ & $34.1(486)$ \\
\hline Brazilian - Not born in the Amazon region & 224 & $37.0(83)$ & $2.7(6)$ & $39.7(89)$ \\
\hline Non-Brazilian & 162 & $1.2(2)$ & $0.0(0)$ & $1.2(2)$ \\
\hline \multicolumn{5}{|l|}{ Colour/race } \\
\hline White & 564 & $27.3(154)$ & $9.2(52)$ & $36.5(206)$ \\
\hline Non-white & 1102 & $20.9(230)$ & $12.8(141)$ & $33.7(371)$ \\
\hline \multicolumn{5}{|l|}{ Sexual orientation } \\
\hline Heterosexual & 1507 & $23.0(346)$ & $11.8(178)$ & $34.8(524)$ \\
\hline Same-sex (including bisexual) & 159 & $23.9(38)$ & $9.4(15)$ & $33.3(53)$ \\
\hline \multicolumn{5}{|l|}{ Marital status ${ }^{\dagger}$} \\
\hline Single, separated or widowed & 1036 & $23.4(242)$ & 10.9 (113) & $34.3(355)$ \\
\hline Married or co-habitating & 630 & $22.5(142)$ & $12.7(80)$ & $35.2(222)$ \\
\hline \multicolumn{5}{|l|}{ Education } \\
\hline No formal education/some elementary school & 1009 & $23.0(232)$ & $10.8(109)$ & $33.8(341)$ \\
\hline Completed elementary school or higher & 657 & $23.1(152)$ & $12.8(84)$ & $35.9(236)$ \\
\hline \multicolumn{5}{|l|}{ Monthly income ${ }^{\dagger}$} \\
\hline Less than Brazilian minimum wage & 1118 & $21.5(241)$ & $11.9(133)$ & $33.4(374)$ \\
\hline More than Brazilian minimum wage & 548 & $26.1(143)$ & $10.9(60)$ & $37.0(203)$ \\
\hline \multicolumn{5}{|l|}{ Income source $^{\dagger}$} \\
\hline Regular or irregular job & 1039 & $21.4(222)$ & $9.7(101)$ & $31.1(323)$ \\
\hline Social benefits/pension & 221 & $14.0(31)$ & $17.2(38)$ & $31.2(69)$ \\
\hline Criminal activity & 406 & $32.3(131)$ & $13.3(54)$ & $45.6(185)$ \\
\hline
\end{tabular}

${ }^{\dagger}$ Last 12 months

\section{Characteristics associated with HCV infection}

The univariate analysis identified the following sociobehavioral characteristics associated with all HCV infection (i.e. active + non-active infections): age $\geq 30$ years, use of crack/oxi + cocaine, daily drug use, > 12 years drug use history, injection drug use, sharing of drug use equipment, involvement in illicit drug trafficking, unsafe sex practices, $>12$ sexual partners, and a history of tattoos (Table 4). The multivariate analysis identified an association of the same ten characteristics with all HCV infection. The Hosmer-Lemeshow test indicated that the final model $\left(\mathrm{HL} \mathrm{X}^{2}=11.23 ; p=0.25\right)$ had an overall good fits. The characteristic most strongly associated with all $\mathrm{HCV}$ infection was an illicit drug use history of $>12$ years $(\mathrm{OR}=27.55)$. Moreover, two characteristics were associated with non-active $\mathrm{HCV}$ infection, or HSC, by way of univariate and multivariate analysis: Brazilian origin (born in the Amazon region) and non-white ethnicity (Table 5). The Hosmer-Lemeshow test indicated that the final model $\left({ }_{\mathrm{HL}} \mathrm{X}^{2}=0.32 ; p=0.59\right)$ had a good fit. 
Table 2 Sample characteristics related to illicit drug use, illicit activities, sex and risks associated with the status of HCV infection

\begin{tabular}{|c|c|c|c|c|}
\hline \multirow[t]{2}{*}{ Characteristics } & \multirow[t]{2}{*}{$\mathrm{N}$} & \multicolumn{3}{|l|}{ HCV infection } \\
\hline & & Active \% (n) & Non-active \% (n) & Total \% (n) \\
\hline Total sample & 1666 & $23.05(384)$ & $11.58(193)$ & $34.63(577)$ \\
\hline \multicolumn{5}{|l|}{ Main illicit drug used ${ }^{a}$} \\
\hline Marijuana & 137 & $9.5(13)$ & $4.4(6)$ & $13.9(19)$ \\
\hline Crack/oxi & 837 & $25.6(214)$ & $11.7(98)$ & $37.3(312)$ \\
\hline Cocaine & 692 & $22.7(157)$ & $12.9(89)$ & $35.6(246)$ \\
\hline Daily use of illicit drugs ${ }^{a}$ & 1153 & $29.0(335)$ & $13.8(159)$ & $42.8(494)$ \\
\hline Over 12 years using illicit drugs & 549 & $56.4(310)$ & $27.0(148)$ & $83.4(458)$ \\
\hline Injecting drug use $\mathrm{e}^{\mathrm{b}}$ & 248 & $37.5(93)$ & $17.3(43)$ & $54.8(136)$ \\
\hline Sharing of drug use equipment ${ }^{a}$ & 988 & $31.5(311)$ & $16.1(159)$ & $47.6(470)$ \\
\hline Involvement in illicit drug trafficking ${ }^{a}$ & 283 & $47.0(133)$ & $18.4(52)$ & $65.4(185)$ \\
\hline Detention (by police or in prison) ${ }^{a}$ & 373 & $22.8(85)$ & $14.7(55)$ & $37.5(140)$ \\
\hline Unprotected sexual intercourse ${ }^{a}$ & 1387 & $25.0(347)$ & $10.7(149)$ & $35.7(496)$ \\
\hline More than 12 sexual partners ${ }^{a}$ & 828 & $26.0(215)$ & $11.6(96)$ & $37.6(311)$ \\
\hline Sex work involvement ${ }^{a}$ & 663 & $21.3(141)$ & $11.9(79)$ & $33.2(220)$ \\
\hline Blood transfusion history & 283 & $31.1(88)$ & $6.7(19)$ & $37.8(107)$ \\
\hline Tattoos & 1082 & $29.4(318)$ & $11.5(124)$ & $40.9(442)$ \\
\hline
\end{tabular}

a Last 12 months. ${ }^{\text {bLast }} 24$ months

Brazilian origin (born in the Amazon region) was the main characteristic associated with HSC $(\mathrm{OR}=8.84)$.

\section{Discussion}

This study identified important characteristics of the study population of PWUIDs in the Amazon region of Northern Brazil and, specifically, associations with $\mathrm{HCV}$ infection status in this vulnerable group. The sample was predominantly composed of men, non-white, young, poor, unmarried, heterosexual and limited education levels. Moreover, some PWUIDs have indicated involvement with sex work, illicit drug trafficking, and the criminal justice system. This information is consistent with findings from other studies in Brazil [13, 18, 21, 29, 30]. Some studies have indicated that socioeconomic marginalization contributes to an increased risk of morbidity and mortality among
PWUIDs [30, 31]. The strong association between HCV infection and involvement with drug trafficking may represent an example of socioeconomic marginalization contributing to increase the health risks of the PWUIDs. The role of these in the specific study sample requires further examination, which should be done in the future.

Crack and cocaine (used mainly non-injection) were the main illicit drugs consumed by study participants. However, many users may be considered poly-drug users, including some of them reporting - occasional - injection drug use at some point in life. Daily drug use and sharing of drug use equipment were characteristics common for most of the study participants. These findings corroborate information provided in other epidemiological studies conducted with PWUIDs in Brazil, including from the Amazon region [16, 17, 19-21, 24-27, 29, 30].

Table 3 Prevalence of infection and distribution of HCV genotypes among people who used illicit drugs

\begin{tabular}{|c|c|c|c|}
\hline \multirow[t]{2}{*}{ Marker } & \multicolumn{2}{|l|}{ Prevalence } & \multirow[t]{2}{*}{$95 \% \mathrm{Cl}$} \\
\hline & Positive/Total & $\%$ & \\
\hline \multicolumn{4}{|l|}{ HCV infection } \\
\hline All $(E \mid A+)$ & $577 / 1666$ & 34.6 & $28.3-41.1$ \\
\hline Active (EIA+ and PCR+) & $384 / 1666$ & 23.0 & $17.9-28.9$ \\
\hline Non-active (EIA+ Immuno Blot+ and PCR -) & $193 / 1666$ & 11.6 & $5.5-18.4$ \\
\hline \multicolumn{4}{|l|}{ Genotypes } \\
\hline Genotype 1 & $308 / 384$ & 80.2 & $75.7-85.2$ \\
\hline Genotype 3 & $72 / 384$ & 18.8 & $12.7-25.0$ \\
\hline Genotype $1+$ Genotype 3 & $4 / 384$ & 1.0 & $0.0-4.6$ \\
\hline
\end{tabular}


Table 4 Bivariate and multivariate analysis of risk factors for HCV infection

\begin{tabular}{|c|c|c|}
\hline \multirow[t]{2}{*}{ Risk factors } & \multicolumn{2}{|l|}{ All HCV infection } \\
\hline & Bivariate OR (95\% Cl) & Multivariate aOR (95\% Cl) \\
\hline \multicolumn{3}{|l|}{ Age } \\
\hline Up to 29 years & 1.00 & 1.00 \\
\hline$\geq 30$ years & $1.29(1.02-1.64)$ & $1.10(1.01-1.75)$ \\
\hline \multicolumn{3}{|l|}{ Main illicit drugs used ${ }^{a}$} \\
\hline Marijuana & 1.00 & 1.00 \\
\hline Crack/oxi + Cocaine & $3.58(2.15-5.87)$ & $3.24(2.03-5.38)$ \\
\hline \multicolumn{3}{|c|}{ Frequency of use of illicit drugs ${ }^{a}$} \\
\hline Non-daily & 1.00 & 1.00 \\
\hline Daily & $3.89(2.96-5.06)$ & $4.01(2.85-5.62)$ \\
\hline \multicolumn{3}{|c|}{ Over 12 years using illicit drugs } \\
\hline No & 1.00 & 1.00 \\
\hline Yes & $29.52(13.47-52.31)$ & $27.55(13.78-50.23)$ \\
\hline \multicolumn{3}{|l|}{ Injection drug use $\mathrm{b}^{\mathrm{b}}$} \\
\hline No & 1.00 & 1.00 \\
\hline Yes & $2.71(2.03-3.57)$ & $3.04(2.35-4.02)$ \\
\hline \multicolumn{3}{|c|}{ Sharing of drug use equipment ${ }^{a}$} \\
\hline No & 1.00 & 1.00 \\
\hline Yes & $4.64(3.80-6.36)$ & $4.18(3.54-6.07)$ \\
\hline \multicolumn{3}{|c|}{ Involvement in illicit drug trafficking ${ }^{a}$} \\
\hline No & 1.00 & 1.00 \\
\hline Yes & $4.77(3.61-7.16)$ & $4.26(3.35-7.49)$ \\
\hline \multicolumn{3}{|c|}{ Unprotected sexual intercourse ${ }^{a}$} \\
\hline No & 1.00 & 1.00 \\
\hline Yes & $1.37(1.02-1.81)$ & $1.22(1.01-1.69)$ \\
\hline \multicolumn{3}{|c|}{ More than 12 sexual partners ${ }^{a}$} \\
\hline No & 1.00 & 1.00 \\
\hline Yes & $1.28(1.05-1.59)$ & $1.19(1.02-1.75)$ \\
\hline \multicolumn{3}{|l|}{ Tattoos } \\
\hline No & 1.00 & 1.00 \\
\hline Yes & $4.14(3.11-5.32)$ & $3.96(2.84-4.95)$ \\
\hline
\end{tabular}

atast 12 months. ${ }^{b}$ Last 24 months. Factors not associated with $\mathrm{HCV}$ infection can be accessed in Additional file 1: Table S1. OR: Odds Ratio. aOR: adjusted Odds Ratio. 95\% Cl: 95\% Confidence interval

The estimated prevalence of $\mathrm{HCV}$ infection in the Amazon region's general population ranges from 1 to $3 \%$, based on the diagnostic methods used, with higher rates being recorded in different sub- or risk groups (e.g., older ages, indigenous) [22, 32-34]. HCV prevalence estimates from previous studies have been multifold higher among PWUIDs, ranging from 28 to $37 \%$, compared to general populations [16, 17, 23-25]. The present study confirmed the high prevalence of $\mathrm{HCV}$ infection (36.6\%) among PWUIDs in the Amazon region, reinforcing the need for effective control and prevention
Table 5 Bivariate and multivariate analysis of factors associated with HCV spontaneous clearance

\begin{tabular}{|c|c|c|}
\hline \multirow[t]{2}{*}{ Factors } & \multicolumn{2}{|c|}{ HCV spontaneous clearance } \\
\hline & $\begin{array}{l}\text { Bivariate OR } \\
(95 \% \mathrm{Cl})\end{array}$ & $\begin{array}{l}\text { Multivariate aOR } \\
(95 \% \mathrm{Cl})\end{array}$ \\
\hline \multicolumn{3}{|l|}{ Origin } \\
\hline $\begin{array}{l}\text { Brazilian + Non-Brazilian - Not born } \\
\text { in the Amazon region }\end{array}$ & 1.00 & 1.00 \\
\hline Brazilian - Born in the Amazon region & $\begin{array}{l}8.84 \\
(3.75-19.81)\end{array}$ & $\begin{array}{l}7.43 \\
(2.54-18.72)\end{array}$ \\
\hline \multicolumn{3}{|l|}{ Colour/race } \\
\hline White & 1.00 & 1.00 \\
\hline Non-White & $\begin{array}{l}1.80 \\
(1.22-2.71)\end{array}$ & $\begin{array}{l}2.02 \\
(1.28-3.11)\end{array}$ \\
\hline
\end{tabular}

Factors not associated with $\mathrm{HCV}$ spontaneous clearance can be accessed in Additional file 1: Table S1. OR Odds Ratio, aOR Adjusted Odds Ratio, 95\% Cl 95\% Confidence interval

measures. The predominance of genotype 1 was observed among PWUIDs, but frequency of the genotype 3 was elevated relative to other risk population in the Amazon region, such as patients with chronic hematologic diseases (recipients of multiple blood transfusions) and patients undergoing hemodialysis [35, 36]. Most $\mathrm{HCV}$ infections in the Amazon region consist of genotype 1 , whereas genotype 3 is found mostly among PWUIDs [16, 17, 24, 32, 35-37]. The rapid spread of genotypes 1 and 3 (and specifically subtypes $1 \mathrm{a}$ and $3 \mathrm{a}$ ), in different geographic areas over the past decades, has been a consequence of efficient transmission through unsafe blood transfusion products and injecting drug use [38-40].

This study is a first in describing HCV infection status (i.e. active and non-active) in a multi-site PWUIDs population in the Amazon region in Northern Brazil. Among 577 PWUIDs infected with HCV, 193 (33.4\%) presented with HCV spontaneous clearance. The multivariate analysis suggested spontaneous clearance status to be strongly associated with origin (Amazonian-born) and non-white (e.g., Black or Indigenous) of the participants. The contemporary population of Northern Brazil is comprised of a heterogeneous socio-ethnic mixture of indigenous Brazilian natives combined with migratory populations of Caucasians and Blacks of diverse origins [41]. Likely, a predominance of indigenous descent, and associated genetic factors, is a variable behind this strong association of socio-ethnic origin with HCV spontaneous clearance. Genetic ancestry analysis markers were not used in this study, but related finding have also been detected in other studies, including native/indigenous people in North America [5, 42]. In Canada, a study conducted with PWUIDs found that Indigenous/Aboriginal status was a factor associated with HCV spontaneous clearance [42]. The understanding of factors that 
promote or prevent the generation of protective immunity is potentially crucial for the development especially of improved prevention (e.g., a possible $\mathrm{HCV}$ vaccine) and/or treatment tools for HCV infection; further studies are needed from a clinical and virological perspective on these issues.

$\mathrm{HCV}$ infection status was associated with several risk factors in this study, most of which have previously been identified by other studies in Brazil [17, 19-21, 24, 43]. The presence of tattoos and older age ( $>30$ years) are characteristic known to be associated with $\mathrm{HCV}$ infection in PWUIDs and Amazonian blood donors [16, 17, $24,25,28,32]$. Longer histories (> 12 years) of illicit drug use was the characteristic most strongly associated with $\mathrm{HCV}$ infection status, implying extended opportunity for and exposure to repeated key risk behaviors facilitating the acquisition of $\mathrm{HCV}$ and other pathogens, such as: sharing of drug use equipment, and injection drug use $[16,17,19-21]$. The active involvement with drug trafficking as a risk factor likely provides quick and easy access to a greater number of different drugs (e.g., injectable cocaine) as well as riskier use methods (e.g., drug injecting), and so provides increased risk pathways to $\mathrm{HCV}$ transmission. Moreover, those newly infected with $\mathrm{HCV}$ can continue to transmit $\mathrm{HCV}$ to other users through the shared use of non-injection equipment (i.e., crack smoking paraphernalia). The possibility of $\mathrm{HCV}$ transmission by shared non-injection equipment has been demonstrated by studies in several countries, including studies in the Amazon region [24, 43-46]. Recently, the presence of HCV-RNA in paraphernalia for crack-cocaine consumption (pipes and aluminum cans) was detected among samples from the Amazon region [46]. Studies have suggested that the risk of HCV transmission by shared non-injection paraphernalia would be modulated by the presence oral wounds and types of paraphernalia (i.e., sharp or heat-intensive materials) used [44-46].

Sexual transmission of HCV is still controversially discussed, but considered possible [47]. Sexual transmission of $\mathrm{HCV}$ has been more commonly recorded in menwho-have-sex-with-men featuring high sexual (e.g., HIV) and drug use risks status [48]. Other studies have indicated the possibility of sexual transmission of $\mathrm{HCV}$ among PWUIDs with sexually transmitted infections (STIs), especially with the presence of oral and/or genital wounds $[49,50]$. High levels of syphilis and HCV-HIV co-infection among PWUIDs have been documented previously in the Amazon region [17, 24, 29, 51]. These dynamics likely are involved in the associations of unprotected sexual intercourse with $\mathrm{HCV}$ infection status in the present study sample. An evaluation of HCV coinfections with other pathogens such as HBV, HIV, HTLV and T. pallidum in the present sample - confounded by poor health care resources and infrastructure in the study region - will be carried out separately to further examine this comprehensive epidemiological-virological picture.

The present study has a number of possible limitations. One limiting factor was the age limit criterion (18 years) applied for eligible participants, since many PWUIDs report an onset of illicit drug use at ages $<18$ years. Second, the restriction of the study to the municipalities of the Amazon region renders the study sample not necessarily representative of the PWUIDs population in Northern Brazil more generally. In addition, although snowball sampling has been found to be adequate for quasi-representative sampling in hidden populations, could have been used to improve representativeness. As the interview data are self-reported, some information, such as drug use or sex-related risks behaviors, may contain response or recall bias. Screening for $\mathrm{HCV}$ infection was based on EIA, recent infections may present a small concentration of anti-HCV antibodies, not yet detected by EIA, and therefore may have been diagnosed as negative. Finally, the cross-sectional design of the study limits its capacity to establish causality.

\section{Conclusions}

The present study is the first epidemiological examination of HCV infection (active or non-active) status and related risk factors among a large, multi-site sample of PWUIDs in the Amazon region. High levels of HCV infection predominantly genotype 1 and associated drug use intensity, sexual risks and social marginalization - as well as spontaneous clearance were identified. The results, despite the context of an underdeveloped health care structure, emphasize the urgent need for improved HCV prevention and care services for marginalized drug users in the Brazilian Amazon region, yet also for improved understanding of $\mathrm{HCV}$ transmission risks and especially those factors facilitating spontaneous clearance for HCV in the study's target population.

\section{Additional file}

Additional file 1: Figure S1. Sample of people who used illicit drugs accessed in each municipality in this study. Table S1. Univariate and multivariate analysis of factors not associated with HCV infection and HCV spontaneous clearance. (DOCX 49 kb)

\section{Abbreviations}

95\% Cl: 95\% Confidence interval; aOR: Adjusted Odds Ratio; CDNA: Complementary DNA; EIA: Enzyme immunoassay; HCV: Hepatitis C virus; HSC: HCV spontaneous clearance; OR: Odds Ratio; PCR: Polymerase chain reaction; PWUIDs: People who used illicit drugs; RIBA: Immuno Blot Assay; RNA: Ribonucleic Acid; UFPA: Universidade Federal do Pará; UNIFAP: Universidade Federal do Amapá; UTR: Untranslated region 


\section{Acknowledgements}

The authors are grateful for the generous assistance of the facilitators who collaborated with the recruitment of the PWUIDs in the study sites. ABOF acknowledges research support from Universidade Federal do Pará, Brazil. RLR acknowledges research support from Universidade Federal do Amapá, Brazil. BF acknowledges research support from the Hugh Green Chair in Addiction Research, Faculty of Medical and Health Sciences, University of Auckland, Auckland, New Zealand, and from the Chair in Addiction, Department of Psychiatry, University of Toronto, Canada.

\section{Authors' contributions}

All authors contributed to the development of research. Study design: ABOF, JARL. Investigation and methodology: ABOF, FJAS, FQS, NCR, CCSC, JNFP, LCM, YMNC, JFFDM, RLR, GCSO, LMLP, LFAM, JRRP, EK, JARL. Formal analysis: ABOF, NCR, LCM, RLR, GCSO, LFAM, JRRP, EK, BF. Writing - original draft: ABOF. Writing - review \& editing: CCSC, NCR, FJAS, FQS, JNFP, LCM, YMNC, JFFDM, RLR, GCSO, LMLP, LFAM, JRRP, EK, JARL, BF. Project administration: ABOF, LCM, RLR, GCSO, LMLP, JARL. Funding acquisition: ABOF, JRRP, JARL, BF. All authors read and approved the final manuscript.

\section{Funding}

Ministério da Saúde/Secretaria de Vigilância em Saúde (MS/SVS) and Conselho Nacional de Desenvolvimento Científico e Tecnológico (CNPQ) provided financial resources for the purchase of reagents and commercial kits used in this study. The authors FJAS, FQS, NCR, YMNC, and JFFDM received CNPQ fellowships to develop the study. The authors CCSC and JNFP received Coordenação de Aperfeiçoamento de Pessoal de Nível Superior (CAPES) fellowships to develop the study.

\section{Availability of data and materials}

The datasets analyzed during the current study are not publicly available due to the progress of analyzes of possible infections and co-infections with other pathogens, but are available from the corresponding author on reasonable request.

\section{Ethics approval and consent to participate}

All participants were included after providing informed and written consent. They received laboratory test results, and participants infected with HCV were directed to treatment in the public health network. All procedures have been performed in accordance with the relevant guidelines and regulations. This study was approved by the Committee for Ethics in Research of the Núcleo de Medicina Tropical of the UFPA in Belém, Brazil (CAAE: 37536314.4.0000.5172).

\section{Consent for publication}

Not applicable.

\section{Competing interests}

The authors declare that they have no competing interests.

\section{Author details}

'Laboratório de Células e Patógenos, Grupo de Estudo e Pesquisa em Populações Vulneráveis (GEPPOV), Instituto de Estudos Costeiros, Campus de Bragança, Universidade Federal do Pará, Alameda Leandro Ribeiro, $s / n$. Aldeia, Bragança, PA, Brazil. '2Laboratório de Patologia Clínica de Doenças Tropicais, Núcleo de Medicina Tropical, Universidade Federal do Pará, Belém, PA, Brazil. ${ }^{3}$ Laboratório de Toxicologia e Química Farmacêutica, Centro de Ciências Biológicas e da Saúde, Universidade Federal do Amapá, Macapá, AP, Brazil. ${ }^{4}$ Faculdade de Ciências Biológicas, Campus do Marajó - Soure, Universidade Federal do Pará, Soure, PA, Brazil. ${ }^{5}$ Laboratório de Virologia, Instituto de Ciências Biológicas, Universidade Federal do Pará, Belém, PA, Brazil. 'Laboratório de Gastroenterologia e Hepatologia, Instituto de Medicina Tropical, Universidade de São Paulo, São Paulo, SP, Brazil. 'Programa de Pós-Graduação Profissional em Análises Clínicas, Instituto de Ciências Biológicas, Universidade Federal do Pará, Belém, PA, Brazil. ${ }^{8}$ Departamento de Saúde Pública, Universidade Federal de Santa Catarina, Florianópolis, SC, Brazil. ' Institute for Mental Health Policy Research, Centre for Addiction and Mental Health (CAMH), Toronto, Canada. ${ }^{10}$ Department of Psychiatry, University of Toronto, Toronto, Canada. ${ }^{11}$ Faculty of Medical and Health Sciences, University of Auckland, Grafton, AK, New Zealand.
Received: 5 March 2019 Accepted: 10 July 2019

Published online: 17 July 2019

\section{References}

1. Te HS, Jensen DM. Epidemiology of hepatitis B and C viruses: a global overview. Clin Liver Dis. 2010;14:1-21. https://doi.org/10.1016/j.cld.2009.11. 009.

2. Lanini S, Easterbrook PJ, Zumla A, Ippolito G. Hepatitis C: global epidemiology and strategies for control. Clin Microbiol Infect. 2016;22:833-8, https://doi.org/10.1016/j.cmi.2016.07.035.

3. Westbrook RH, Dusheiko G. Natural history of hepatitis C. J Hepatol. 2014;61: S58-68. https://doi.org/10.1016/j.jhep.2014.07.012.

4. Asselah T, Boyer N, Saadoun D, et al. Direct-acting antivirals for the treatment of hepatitis $C$ virus infection: optimizing current IFN-free treatment and future perspectives. Liver Int. 2016;36:47-57. https://doi.org/1 0.1111/liv.13027.

5. Aisyah DN, Shallcross L, Hully AJ, et al. Assessing hepatitis C spontaneous clearance and understanding associated factors - a systematic review and meta-analysis. J Viral Hepat. 2018;25:680-98. https://doi.org/10.1111/jvh.12 866.

6. Cunningham EB, Applegate TL, Lloyd AR, et al. Mixed HCV infection and reinfection in people who inject drugseimpact on therapy. Nat Rev Gastroenterol Hepatol. 2015;12:218-30. https://doi.org/10.1038/nrgastro.2 015.36 .

7. Layden JE, Phillips RO, Owusu-Ofori S, et al. High frequency of active HCV infection among seropositive cases in West Africa and evidence for multiple transmission pathways. Clin Infect Dis. 2015;60:1033-41. https://doi.org/10.1 093/cid/ciu965.

8. Aceijas C, Rhodes T. Global estimates of prevalence of HCV infection among injecting drug users. Int J Drug Policy. 2007;18:352-8. https://doi.org/10.1 016/j.drugpo.2007.04.004

9. Scheinmann $\mathrm{R}$, Hagan $\mathrm{H}$, Lelutiu-Weinberger $\mathrm{C}$, et al. Non-injection drug use and hepatitis C virus: a systematic review. Drug Alcohol Depend. 2007;89:112. https://doi.org/10.1016/j.drugalcdep.2006.11.014.

10. Mathers BM, Degenhardt L, Phillips B, et al. Global epidemiology of injecting drug use and HIV among people who inject drugs: a systematic review. Lancet. 2008;372:1733-45. https://doi.org/10.1016/S0140-6736(08)61311-2.

11. Degenhardt $L$, Hall W. Extent of illicit drug use and dependence, and their contribution to the global burden of disease. Lancet. 2012;379:55-70. https://doi.org/10.1016/S0140-6736(11)61138-0.

12. Nelson PK, Mathers BM, Cowie B, et al. Global epidemiology of hepatitis B and hepatitis $C$ in people who inject drugs: results of systematic reviews. Lancet. 2011;13:571-83. https://doi.org/10.1016/S0140-6736(11)61097-0.

13. Duailibi LB, Ribeiro M, Laranjeira R. Profile of cocaine and crack users in Brazil. Cad Saude Publica. 2008;24:545-57. https://doi.org/10.1590/S0102-311 X2008001600007.

14. Fischer B, Santos Cruz M, Bastos Fl, et al. Crack across the Americas - a massive problem in continued search of viable answers: exemplary views from the north (Canada) and the south (Brazil). Int J Drug Policy. 2013;24: 631-3. https://doi.org/10.1016/j.drugpo.2013.09.003.

15. United Nations Office on Drugs and Crime. World Drug Report 2012 , 2012. https://www.unodc.org/documents/po-brazil/Topics_drugs/WDR/2 012/WDR_2012_web_small.pdf. Accessed 3 Aug 2018.

16. Oliveira-Filho $A B$, Sawada $L$, Pinto $L C$, et al. HCV infection among cocaine users in the state of Pará, Brazilian Amazon. Arch Virol. 2013;158:1555-60. https://doi.org/10.1007/s00705-013-1627-5.

17. Silva FQ, Santos FJA, Andrade AP, et al. Hepatitis C virus infection among illicit drug users in an archipelago of the Amazon. Arch Virol. 2018;163:61722. https://doi.org/10.1007/s00705-017-3656-y.

18. Abdalla RR, Madruga CS, Ribeiro M, et al. Prevalence of cocaine use in Brazil: data from the II Brazilian national alcohol and drugs survey (BNADS). Addict Behav. 2014;39:297-301. https://doi.org/10.1016/.addbeh.2013.10.019.

19. Lopes $\mathrm{CL}$, Teles SA, Espírito-Santo MP, et al. Prevalence, risk factors and genotypes of hepatitis $C$ virus infection among drug users, Central-Western Brazil. Rev Saude Publica. 2009;43:43-50. https://doi.org/10.1590/50034-891 02009000800008.

20. Oliveira ML, Yoshida CF, Telles PR, et al. Trends in HCV prevalence, risk factors and distribution of viral genotypes in injecting drug users: findings from two cross-sectional studies. Epidemiol Infect. 2009;137:970-9. https:// doi.org/10.1017/S0950268808001970. 
21. Nunes CL, Andrade T, Galvão-Castro B, et al. Assessing risk behaviors and prevalence of sexually transmitted and blood-borne infections among female crack cocaine users in Salvador-Bahia, Brazil. Braz J Infect Dis. 2007;11:561-6. https://doi.org/10.1590/S1413-867020070006 00007.

22. Pereira LM, Martelli CM, Moreira RC, et al. Prevalence and risk factors of hepatitis C virus infection in Brazil, 2005 through 2009: a crosssectional study. BMC Infect Dis. 2013;13:60. https://doi.org/10.1186/14 71-2334-13-60.

23. Silva MB, Andrade TM, Silva LK, et al. Prevalence and genotypes of hepatitis $C$ virus among injecting drug users from Salvador-BA, Brazil. Mem Inst Oswaldo Cruz. 2010;105:299-303. https://doi.org/10.1590/S0074-0276201 0000300009.

24. Oliveira-Filho AB, Sawada L, Pinto LC, et al. Epidemiological aspects of HCV infection in non-injecting drug users in the Brazilian state of Pará, eastern Amazon. Virol J. 2014;11:38. https://doi.org/10.1186/1743-422X-11-38.

25. Pacheco SD, Silva-Oliveira GC, Maradei-Pereira LM, et al. Prevalence of HCV infection and associated factors among illicit drug users in Breves, State of Pará, Northern Brazil. Rev Soc Bras Med Trop. 2014;47:367-70. https://doi. org/10.1590/0037-8682-0153-2013.

26. Andrade AP, Pacheco SD, Silva FQ et al. Characterization of hepatitis B virus infection in illicit drug users in the Marajó archipelago, Northern Brazil. Arch Virol. 2017;162:227-33. https://doi.org/10.1007/s00705-016-3060-z.

27. Furtado IM, Araujo LG, Almeida JM, et al. Use of marijuana and cocaine among students in the municipality of Breves, Marajó archipelago, Brazilian Amazon. J Drug Abuse. 2017;3:1. https://doi.org/10.21767/2471-853x.100041.

28. Valois RC, Maradei-Pereira LMC, Crescente JA, et al. HCV infection through perforating and cutting material among candidates for blood donation in Belém, Brazilian Amazon. Rev Inst Med Trop Sao Paulo. 2014;56:511-5. https://doi.org/10.1590/S0036-46652014000600010.

29. Santos FJA, Silva FQ, Reis ER, et al. Cocaine and their derivatives: initial report on the features and health indicators of users in municipalities of the Brazilian Amazon. In: Drug Addiction; 2017. http://www.avidscience.com/ wp-content/uploads/2017/10/cocaine-and-their-derivatives-initial-report-onthe-features-and-health-indicators-of-users-in-municipalities-of-the-brazilianamazon.pdf. Accessed 3 Aug 2018.

30. Santos Cruz M, Andrade T, Bastos Fl, et al. Key drug use, health and socioeconomic characteristics of young crack users in two Brazilian cities. Int J Drug Policy. 2013;24:432-8. https://doi.org/10.1016/j.drugpo.2013.03.012.

31. Butler AJ, Rehm J, Fischer B. Health outcomes associated with crack-cocaine use: systematic review and meta-analyses. Drug Alcohol Depend. 2017;180: 401-16. https://doi.org/10.1016/j.drugalcdep.2017.08.036.

32. Oliveira-Filho AB, Pimenta AS, Rojas MF, et al. Prevalence and genotyping of hepatitis $C$ virus in blood donors in the state of Pará, Northern Brazil. Mem Inst Oswaldo Cruz. 2010;105:103-6. https://doi.org/10.1590/S0074-0276201 0000100016

33. Ferrari JO, Ferreira MU, Tanaka A, et al. The seroprevalence of hepatitis B and $\mathrm{C}$ in an Amerindian population in the southwestern Brazilian Amazon. Rev Soc Bras Med Trop. 1999;32:299-302.

34. De Paula VS, Arruda ME, Vitral CL, et al. Seroprevalence of viral hepatitis in riverine communities from the western region of the Brazilian Amazon Basin. Mem Inst Oswaldo Cruz. 2001;96:1123-8. https://doi.org/10.1590/ S0074-02762001000800016.

35. Freitas MJR, Fecury AA, de Almeida MK, et al. Prevalence of hepatitis C virus infection and genotypes in patient with chronic kidney disease undergoing hemodialysis. J Med Virol. 2013;85:1741-5. https://doi.org/10.1002/ jmv.23654.

36. Sawada $L$, Pinheiro AC, Locks $D$, et al. Distribution of hepatitis $C$ virus genotypes among different exposure categories in the State of Pará, Brazilian Amazon. Rev Soc Bras Med Trop. 2011;44:8-12. https://doi.org/1 0.1590/S0037-86822011000100003.

37. Araújo AR, Almeida CM, Fraporti $L$, et al. Characterization of hepatitis C virus in chronic hepatitis patients: genotypes in the State of Amazonas, Brazil. Rev Soc Bras Med Trop. 2011;44:638-40. https://doi.org/10.1590/S0037-86822011 000500024

38. Prati D. Transmission of hepatitis $C$ virus by blood transfusions and other medical procedures: a global review. J Hepatol. 2006;45:607-16. https://doi. org/10.1016/j.jhep.2006.07.003.

39. Pybus OG, Cochrane A, Holmes EC, et al. The hepatitis $C$ virus epidemic among injecting drug users. Infect Genet Evol. 2005:5:131-9. https://doi. org/10.1016/j.meegid.2004.08.001.
40. Robaeys G, Bielen R, Azar DG, et al. Global genotype distribution of hepatitis C viral infection among people who inject drugs. J Hepatol. 2016:65:1094103. https://doi.org/10.1016/j.jhep.2016.07.042.

41. Callegari-Jacques SM, Grattapaglia D, Salzano FM, et al. Historical genetics: spatiotemporal analysis of the formation of the Brazilian population. Am J Hum Biol. 2003;15:824-34.

42. Grebely J, Raffa JD, Lai C, et al. Factors associated with spontaneous clearance of hepatitis C virus among illicit drug users. Can J Gastroenterol. 2007:21:447-51.

43. Sá LC, Araújo TM, Griep RH, et al. Seroprevalence of hepatitis $C$ and factors associated with this in crack users. Rev Lat Am Enfermagem. 2013;21:1195202. https://doi.org/10.1590/0104-1169.3126.2354.

44. Aaron S, McMahon JM, Milano D, et al. Intranasal transmission of hepatitis C virus: virological and clinical evidence. Clin Infect Dis. 2008;47:931-4. https:// doi.org/10.1086/591699.

45. Fischer B, Powis J, Firestone Cruz $M$, et al. Hepatitis $C$ virus transmission among oral crack users: viral detection on crack paraphernalia. Eur J Gastroenterol Hepatol. 2008;20:29-32. https://doi.org/10.1097/MEG.0b013e32 $82 \mathrm{f} 16 \mathrm{a} 8 \mathrm{c}$.

46. Reis GKM, Brito NAV, Amaral CEM, et al. Detecção de ácido nucléico viral em equipamento para uso de crack: será que o vírus da hepatite $C$ pode ser transmitido pelo uso compartilhado de cachimbos? In: V Convibra Gestão, Educação e Promoção da Saúde: Melhores Artigos (Portuguese Edition); 2017. https://www.amazon.com/Convibra-Educa\%C3\%A7\%C3\%A3 o-Promo\%C3\%A7\%C3\%A3o-Melhores-Portuguese-ebook/dp/B073D9FNKT. Accessed 3 Aug 2018.

47. Thursz M, Fontanet A. HCV transmission in industrialized countries and resource-constrained areas. Nat Rev Gastroenterol Hepatol. 2014;11:28-35. https://doi.org/10.1038/nrgastro.2013.179.

48. Urbanus AT, van de Laar TJ, Stolte IG, et al. Hepatitis C virus infections among HIV-infected men who have sex with men: an expanding epidemic. AIDS. 2009;23:F1-7. https://doi.org/10.1097/QAD.0b013e32832e5631.

49. Hershow RC, Kalish LA, Sha B, et al. Hepatitis C virus infection in Chicago women with or at risk for HIV infection: evidence for sexual transmission. Sex Transm Dis. 1998;25:527-32.

50. Marx MA, Murugavel KG, Tarwater PM, et al. Association of hepatitis c virus infection with sexual exposure in southern India. Clin Infect Dis. 2003:37: 514-20. https://doi.org/10.1086/376639.

51. Sousa RAC, Marques EM, Frade PCR, et al. Syphilis among illicit drugs users in the state of Pará, Brazilian Amazon. In: Tropical Medicine; 2017. http:// www.avidscience.com/wp-content/uploads/2017/08/syphilis-among-illicitdrugs-users-in-the-state-of-par\%C3\%A1-brazilian-amazon.pdf. Accessed 3 Aug 2018.

\section{Publisher's Note}

Springer Nature remains neutral with regard to jurisdictional claims in published maps and institutional affiliations.

Ready to submit your research? Choose BMC and benefit from:

- fast, convenient online submission

- thorough peer review by experienced researchers in your field

- rapid publication on acceptance

- support for research data, including large and complex data types

- gold Open Access which fosters wider collaboration and increased citations

- maximum visibility for your research: over $100 \mathrm{M}$ website views per year

At $\mathrm{BMC}$, research is always in progress.

Learn more biomedcentral.com/submissions 